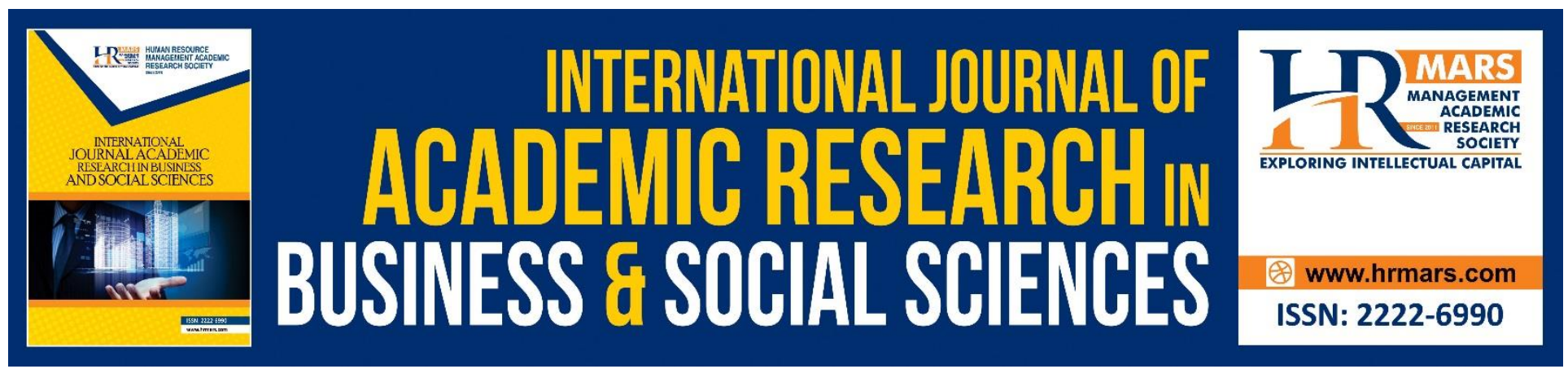

\title{
The Impact of Media Consumption Habits upon the Quality of Life
}

\section{Florescu Decebal-Remus}

To Link this Article: http://dx.doi.org/10.6007/IJARBSS/v8-i9/4655

DOI: $\quad 10.6007 /$ IJARBSS/v8-i9/4655

Received: 11 August 2018, Revised: 03 Sept 2018, Accepted: 29 Sept 2018

Published Online: 15 October 2018

In-Text Citation: (Decebal-Remus, 2018)

To Cite this Article: Decebal-Remus, F. (2018). The Impact of Media Consumption Habits upon the Quality of Life. International Journal of Academic Research in Business and Social Sciences, 8(9), 794-815.

\section{Copyright: (C) 2018 The Author(s)}

Published by Human Resource Management Academic Research Society (www.hrmars.com)

This article is published under the Creative Commons Attribution (CC BY 4.0) license. Anyone may reproduce, distribute, translate and create derivative works of this article (for both commercial and non-commercial purposes), subject to full attribution to the original publication and authors. The full terms of this license may be seen

at: http://creativecommons.org/licences/by/4.0/legalcode

Vol. 8, No. 9, September 2018, Pg. 794 - 815

http://hrmars.com/index.php/pages/detail/IJARBSS

JOURNAL HOMEPAGE

Full Terms \& Conditions of access and use can be found at http://hrmars.com/index.php/pages/detail/publication-ethics 


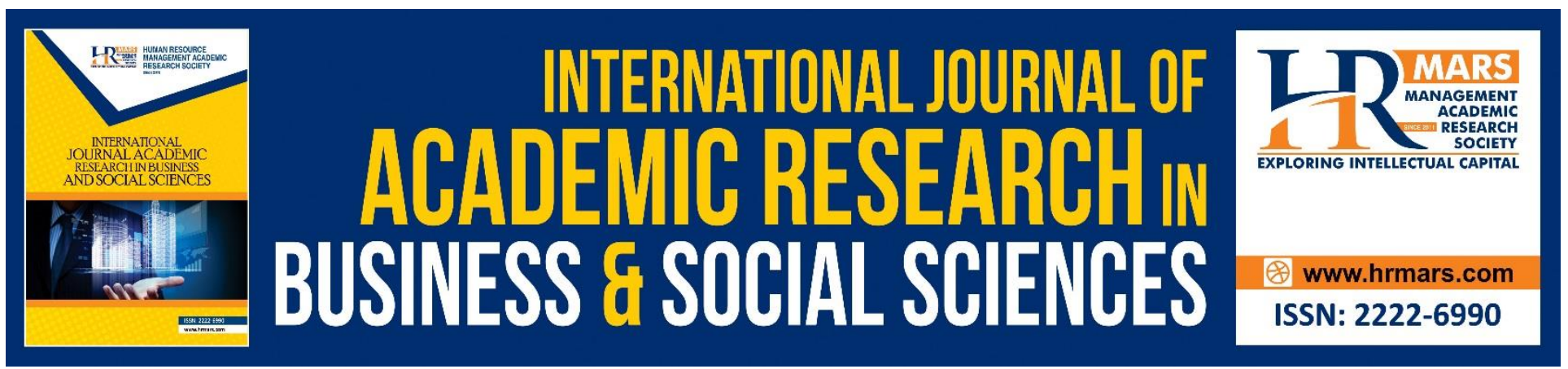

\title{
The Impact of Media Consumption Habits upon the Quality of Life
}

\author{
Florescu Decebal-Remus \\ "Babeș-Bolyai” University Cluj-Napoca, Faculty of Political, Administrative and Communication \\ Sciences, Romania
}

\begin{abstract}
In the digital age, more than ever throughout the history of mankind, the aphorism information is power applies. The purpose of this paper is to find out if there is a relation between media consumption and the quality of life in countries from the European Union. The paper evaluates the impact of European consumption habits regarding written press, radio, television and internet upon the life standards of the society as they are reflected in three of the most important worldwide used indexes for their measurement: the Quality of Life Index, the Human Development Index and the Global Knowledge Index. The conclusion of the study is that countries from the European Union in which written press is highly "consumed" have the highest quality of life and knowledge.
\end{abstract}

Keywords: Media Consumption, Press, Human Development, Quality Of Life, Written Press, Internet, Radio, Television

\section{Introduction}

The quality of life of people is a concern for scientists and governments all around the Globe. Indicators like material living conditions, health, education, leisure and social interactions, economic and physical safety, governance and basic rights, natural and living environment and so on are aggregated by different organizations that regularly publish different rankings of countries according to these combined indicators.

Since the beginning of the 21st century the World has changed in almost every aspect by the Information Age (Computer Age, Digital Age, or New Media Age), a historic period characterized by the rapid shift from a traditional industry that the Industrial Revolution brought through industrialization, to an economy based on information technology. Information has become one of the most valuable currencies in economy. The companies invest millions of dollars in order to have the best and the newest information, because their prosperity depends on it. But the following question arises: how important is information for the citizens of the countries? Is it important for their wellbeing and for the democracy? Citizens get their information from mass media, so this paper evaluates the impact various media variables have upon the life standards, the development and knowledge of European nations. 
Information means not only power in the present day society, as futurist Alvin Toffler predicted (Toffler, 1990), but information also means a better life in the broad sense of the expression. So the main research hypothesis is that countries from the European Union in which written press is highly "consumed" have the highest quality of life and knowledge. By further extrapolating it to the entire mass-media, its impact upon the socio-economic development and growth of nations' well-being is extremely important.

The structure of this paper is organized on a review of some of the literature related to the research topic, the presentation of the collected data and the applied methodology, the comments for the obtained results and a last part that discusses the implications and draws conclusions.

This paper's findings are in line with previous research on the use of social technologies (various platforms and networks) and their relationship to economic development (Nord et al, 2016) and social development (Din et al, 2012; Campisi et al, 2015) or the both (Growiec et al, 2018). Moreover, this paper brings an original contribution by analyzing the relationship between citizens' consumption of written press, radio, television, internet and three different indexes that reflect the quality of life of EU-28 countries.

\section{Literature Review}

Researchers have been preoccupied by the various dimensions of the quality of life of a population, many research variables surpassing the Gross Domestic Product (GDP) indicator that has been traditionally used as the measure of a country's economic development. Although this paper initially considered the real GDP growth rate as one of its potential dependent variables, actually the life standards of a country are a multidimensional phenomenon, so other complex indexes are further analyzed as dependent variables.

The Eurostat Quality of Life Indicators online publication considers 8+1 domains for defining an overarching framework for the measurement of well-being. According to this publication, they should be considered simultaneously, because of potential trade-offs between them: material living conditions (income, consumption and material conditions), productive or main activity, health, education, leisure and social interactions, economic and physical safety, governance and basic rights, natural and living environment and the overall experience of life. The latter reflects the overall subjective well-being of persons, as the only way to integrate the diversity of the experiences, choices, priorities and values of an individual (Quality of Life Indicators, 2015). Other researchers explain the multidimensional construct of the quality of life by referring to an individual's or nation's overall subjective well-being and life satisfaction in the context of culture and value systems and in relation to goals, expectations and concerns (Campisi et al 2015, citing Lawton et al, 1999, 2001)

Broad human development has brought along an increased quality of life in all its subdomains. Novel et al.(2008) refers to human development as a concept whose primary objective is to promote human freedoms, for example by increasing the choices offered to individuals, enabling them to live a full life and benefit from factors of progress and what they generate. To the authors, human development is both a process of expanding people's choices and the outcome of the choices that it offers them. This paper is interested in the influences various media variables have upon the development and well-being of European nations. 
Media hold a key role in nowadays societies. Practically, media organizations have always held a strong position within society through the impact and influence of their content. They have always played an important role in supporting progress towards a sustainable society because the freedom of expression they promote is a fundamental element of the Universal Declaration of Human Rights. Moreover, media organizations are strongly related to the information and education fields, because they equip citizens with the necessary tools and knowledge to be informed and educated. Furthermore, through the entertainment and news they provide, media organizations offer a means by which global and local societies learn about themselves and each other. They thereby build a sense of community and inter-cultural dialogues which shape the understanding of values, customs and traditions. Nevertheless, media organizations have the capacity to inform, create debate and engagement around key sustainability issues such as pressing environmental matters, human rights, economic and social justice, and wellbeing (G4 Sector Disclosures, 2014).

Locksley (2009) considers that media represents a combination of content-music, films, TV, radio, publishing, advertisements, and electronic games-along with their associated technological devices. Because of the fact that the media has always been closely related to the technological progress, its contents, platforms and devices have continuously evolved and changed over centuries. Locksley (2009) analyses the impact the media have on the development process using several closely intermingled influences, like plurality and transparency (the contributions that a plural media environment makes to good governance, transparency, and the functioning of economic and political markets); behavioral (the media's contribution to inspiring beneficial changes in the behaviors of individuals and organizations, given by the huge amounts spent on global advertising) or economic (the business of producing content generates substantial income flows and creates a significant number of jobs, directly contributing to development and poverty reduction).

Press is considered to be the fourth power in a state, so press freedom and its improvement is a key issue. If up to Novel et al. (2008), previous research studies focused on the idea that human, economic and social development was promoted through a free press, this research team tests the correlations between press freedom and human development, having as a central hypothesis the idea that freedom of the press has a positive impact on all dimensions of human development. The report evaluates the beneficial impact the freedom of press brings along upon tens of economic, educational or governance variables.

MDIF (2014) also provides evidence suggesting that a quality and independent media has a positive impact on society and should be viewed as a critical development outcome in itself. Its governance, economic and social impact are further referred to in detail. For the economic development of a nation, media improves the efficiency of its economy by providing actors more and better information with which to take decisions and improve stability. Media enhances political coordination in the development of sound economic policy, by playing a mediator role between the political decision factors and the economic policies they draw. Coyne \& Leeson (2002) argued that a successful economic development is characterized by widespread coordination and the development of free media is critical for shifting games of conflict to games of coordination. Their paper reviews a number of historic case studies, including successful economic development examples such as Poland and Hungary, and less successful ones including Ukraine. In the successful cases of Poland and Hungary, "not only has the media played a role in transforming situations of conflict into 
coordination, but also access to information has allowed politicians and the population to coordinate on good conjectures leading to economic progress". So free media is strictly related to a successful economic development. Furthermore, from the points of view of companies and their stakeholders, researchers have been concerned by the role of media in corporate governance. Liu \& McConnell (2013) investigate to what extent managers of publicly traded US corporations are sensitive to the level and the tone of public news media for making capital allocation decisions, on a sample of 636 large acquisition attempts accompanied by a negative stock price reaction at their announcement. Their paper sustains that the media are key conduits through which managers' reputational capital is built and potentially, destroyed. Their results imply that the media plays a positive role for the capital allocation in a market economy. Nonetheless, there exist studies that link the optimism of media reporting to portfolio return premiums, suggesting that media sentiment influences trade sentiment and thereby market prices. (Walker, 2016)

Besides the economic implications of media, there also exist strong social implications. MDIF (2014) argues that media catalyzes positive changes in society by providing the information that influences public opinion. For supporting this idea, the review further states that media leads to increases in awareness and changes in behavior across social issues (e.g. public health issues and others) and, nevertheless, information access is linked to less environmental degradation. For example, Trivedi et al (2018) analyze the formation of green behaviors by including the role played by media and attitude towards environmental-friendly packaging, along with ecological concerns. Their findings imply that media significantly influence the ecological concerns of consumers and media's ever-increasing attention to highlight various environmental issues can really shape higher ecological concerns among consumers.

\section{An evolutionary perspective of media}

One of the inventions that has had a huge impact on the development of human society is the technology of printing. Although some form of printing dated back to 220 A.D. in China, the printing press which changed the world was invented by Johannes Gutenberg in the 15th century (around the year 1450). In 1997, Time-Life magazine picked Gutenberg's invention as the most important of the second millennium. "The technology of printing played a key role in the development of the Renaissance and the scientific revolution, and laid the material basis for the modern knowledgebased economy and the spread of learning to the masses" (Rees, 2005).

A hundred and fifty years after the invention of the printing press, the first newspaper appeared. The German-language "Relation aller Fürnemmen und gedenckwürdigen Historien" (Account of all distinguished and commemorable news), printed from 1605 onwards by Johann Carolus in Strasbourg, has been recognized as the first newspaper in the world. (Weber, 2005). By the early 19th century, many cities in Europe, as well as North and South America, issued newspapertype publications though not all of them developed in the same way; content was vastly shaped by regional and cultural preferences (Britannica Online Encyclopedia). In 1830, the first inexpensive "penny press" newspaper came to the market: Lynde M. Walter's Boston Transcript. Penny press papers cost about one sixth of the price of other newspapers and appealed to a wider audience, including less educated and lower-income people (Bird, 1992). 
INTERNATIONAL JOURNAL OF ACADEMIC RESEARCH IN BUSINESS AND SOCIAL SCIENCES Vol. 8, No. 9, Sept. 2018, E-ISSN: 2222-6990 @ 2018 HRMARS

Closer to the present days, according to Barthel M. (2016), 55 percent of people reported that print was their preferred method for reading a newspaper, down with $4 \%$ as compared to the previous year. According to the same source, regarding the methods people use to get their news from, the trends indicate an increase in digital consumption of newspapers, as opposed to less people attaining the news through printed newspapers.

The saga of newspapers continues today with new struggles caused by the digital age that has changed the whole society dramatically and has put an increased pressure on journalists to adapt to the new ways people live and consume information.

The origin of radio dates all the way back to the 1820's when the relationship between electricity and magnetism was found, but the first radio news programs date between 1916 and 1920 that the first known radio news program was broadcast (Sterling, 2004). Radio became a new form of communication, entertainment and also an educational tool. "The golden age of radio" was between the 1920 and 1950, when the small wooden box was the main provider of news, sports broadcasts, comedy shows, dramas, live music and political shows in every household (Diggs-Brown, 2012). In the 30s, radio began to gain popularity in the area of education: many felt that radio had the power to bring the world to the classroom, and that radio programs could be presented as if they were textbooks of the air (Lindgren, 2004). Radio was also a way of sharing new progressive ideas: „Radio programs opened up the arena to discussing contemporary progressive ideas and political notions. These progressive ways of thinking were not readily available to students in a classroom. Children who listened to educational radio encountered views of society that were much different than the views that were shown in their school books" (Lindgren, 2004). This changed during the 1950s, when television became the primary medium for influencing public opinion (Diggs-Brown, 2012).

Out of all media, television has been one of the most criticized in the last tens of years. Postman (2006) said that television "has turned our society into an audience that is dependent on the need for constant entertainment". He also suggests that "television is altering the meaning of being informed by creating a species of information that might properly be called disinformation. Disinformation does not mean false information. It means misleading information - misplaced, irrelevant, fragmented or superficial information - information that creates the illusion of knowing something, but which in fact leads one away from knowing" (Postman, 2006). Another fierce critic of television, Mander (1977) says „Television limits and confines human knowledge. It changes the way humans receive information from the world. In place of multidimensional information reception, it offers a very narrow-gauged sense of experience, diminishing the amount and kind of information people receive. Television keeps awareness contained within its own rigid channels, a tiny fraction of the natural information filed. Because of television we believe we know more, but we know less". Mander also says that television "affects the psychology of people who watch. It increases the passivity of people who watch. It changes family relationships. It changes understandings of nature. It flattens perception so that information, which you need a fair amount of complexity to understand it as you would get from reading, this information is flattened down to a very reduced form on television. And the medium has inherent qualities which cause it to be that way." (Kubiak, 2012). Furthermore, understanding the roles media plays and its impact upon the development of nations as having a huge importance, the author comes with alternatives to television: "Simultaneity is 
provided by radio. It's also a less expensive, easier medium for people to use, easier for people to receive. If something is happening in Borneo that you must know right now, radio is much more likely to get it than television. Print media is much better for complexity and detail and depth and historical context. And movies are better for a visual medium and have far more impact. So, other media do what television does except better. The only thing that television does that other media do not do is that it goes into the homes of an entire nation night after night after night. It puts images into everyone's heads at the same time and it's controlled by a very small number of people". (Kubiak, 2012). He concludes that one of the advantages of living without television is that people would try more to change the reality of their own lives and of the lives of others: "What is lost by the unavailability of escape from what may be the painful conditions of many people's lives, might be more than offset by the concrete realizations that life has been made painful, more to some than to others, and the desire to do something about this, to attack whatever forces have conspired to make this so" (Mander, 1977).

\section{Data and Methodology}

This paper uses the most recent cross-sectional data for the EU-28 countries, i.e. for the year 2017. The purpose for using the latest available indicators is to have an up-to-date image of the impact several media variables have upon the development of European nations.

\section{The Dependent Variables}

The Quality of Life Index (QLI) (higher is better) is an estimation of overall quality of life by using an empirical formula which takes into account purchasing power index (higher is better), pollution index (lower is better), house price to income ratio (lower is better), cost of living index (lower is better), safety index (higher is better), health care index (higher is better), traffic commute time index (lower is better) and climate index (higher is better). Using user contributed data about cities and countries worldwide, the formula for weighting these components and determining the final value of QLI has varied along the last years. In November 2015, the index was adjusted by including the climate index. This paper uses the country values of the QLI for 2017. The QLI ranges from 0 points in Venezuela to 190.37 points Austria, containing data for 67 reported countries.

The latest Human Development Index (HDI) was published in 2017 for the data in 2015 or the most recent year available. The 2016 Human Development Report is the latest in the series of global Human Development Reports published by the United Nations Development Programme (UNDP) since 1990 as independent, analytically and empirically grounded discussions of major development issues, trends and policies. According to the United Nations Development Programme, the Human Development Index (HDI) is a summary measure of average achievement in key dimensions of human development: a long and healthy life (proxied by the life expectancy at birth), being knowledgeable (the indicators here are the expected years of schooling and the average years of schooling) and have a decent standard of living (the gross national income per capita in USD Power-Purchasing Parity). The HDI is the geometric mean of normalized indices for each of these three dimensions. The HDI was created to emphasize that people and their capabilities should be the ultimate criteria for assessing the development of a country, not economic growth alone. HDI ranks worldwide countries into four groups: very high human development, high human development, medium human 
development and low human development European countries belong to the first two categories, mainly to the first (out of EU-28, only Bulgaria is ranked as a high human development country, the other countries being very high human development countries). The World HDI is 0.717 , and all the EU-28 countries are above this world average value of the index. The best ranked country is Norway with a HDI of 0.949 .

The Global Knowledge Index (GKI) is the only index that measures knowledge on the global level. The GKI aims at measuring knowledge as a broad concept that is intricately related to all aspects of modern human life, in a systematic approach that builds on solid conceptual and methodological principles. As such, the GKI is composed of six sectoral indices: (1) Pre-University Education, (2) Technical Vocational Education and Training (TVET), (3) Higher Education, (4) Research, Development and Innovation (RDI), (5) Information and Communications Technology (ICT), (6) and Economy, in addition to a seventh supporting index on the General Enabling Environment. Each of these seven indices was constructed in accordance with standard international methodologies for the design of composite indicators. Moreover, the GKI is structured with a hierarchy of five levels: index, constituting indices (also referred to as sectoral indices), pillars, sub-pillars and variables. Each of the six sectoral indices has a weight of 15 percent, while the general enabling environment has a weight of 10 percent. The GKI is a partnership initiative between the United Nations Development Programme (UNDP) and Mohammed Bin Rashid Al Maktoum Knowledge Foundation (MBRF), being firstly announced during the Knowledge Summit in 2016. The index is computed for 131 countries, the best ranked country being Switzerland (GKI of 71.8) and the lowest ranked country being Yemen (GKI of 25.2).

\section{The Independent Variables}

The explanatory variables are taken from the Media Usage in Europe Statista Report, that bases its results on data published by European Commission. The independent variables of this study are the following: the usage frequency of written press (Written_Press), the daily radio usage (Radio), the daily television usage penetration rate (TV), the daily internet usage penetration (Internet) and the social network usage penetration rate (Social_Networks), for the European populations in 2017. The original source of data is the Standard Eurobarometer 88: Media Use in the European Union, that gathered the data from 28055 respondents aged 15 or above. The respondents represent the whole territory of the EU-28 countries surveyed. The survey's period was November 5-19, 2017, but the synthesized results were published in April 2018 by the European Commission. The description is given in Table 1. 
INTERNATIONAL JOURNAL OF ACADEMIC RESEARCH IN BUSINESS AND SOCIAL SCIENCES Vol. 8, No. 9, Sept. 2018, E-ISSN: 2222-6990 @ 2018 HRMARS

Table 1 Description of variables

\begin{tabular}{|c|c|c|c|}
\hline Variables & Way of expressing & Units/scale & Sources \\
\hline \multicolumn{4}{|l|}{ Dependent variables } \\
\hline $\begin{array}{l}\text { Quality of Life } \\
\text { Index for countries }\end{array}$ & $\begin{array}{l}\text { Quality of Life Index (QLI) estimates } \\
\text { the overall quality of life by } \\
\text { aggregating its purchasing power } \\
\text { index, pollution index, house price } \\
\text { to income ratio, cost of living index, } \\
\text { safety index, health care index, } \\
\text { traffic commute time index and } \\
\text { climate index. }\end{array}$ & $\begin{array}{l}\text { Ranges from } 0 \text { to } \\
190.37 \text { points. }\end{array}$ & Numbeo $^{1}, 2017$ \\
\hline $\begin{array}{l}\text { Human Development } \\
\text { Index }\end{array}$ & $\begin{array}{l}\text { The Human Development Index } \\
\text { (HDI) is a summary measure of } \\
\text { average achievement in key } \\
\text { dimensions of human development: } \\
\text { a long and healthy life, being } \\
\text { knowledgeable and have a decent } \\
\text { standard of living; it is used for } \\
\text { reflecting the progress of countries. }\end{array}$ & Ranges from 0 to 1. & $\begin{array}{l}\text { United Nations, } \\
2017\end{array}$ \\
\hline $\begin{array}{l}\text { Global Knowledge } \\
\text { Index }\end{array}$ & $\begin{array}{l}\text { The Global Knowledge Index (GKI) } \\
\text { introduces a more systematic } \\
\text { understanding of knowledge by } \\
\text { breaking down the concept into its } \\
\text { constituent components - i.e. } \\
\text { education, economy, research and } \\
\text { technology. }\end{array}$ & $\begin{array}{l}\text { Ranges from } 0 \text { to } 71.8 \\
\text { points. }\end{array}$ & $\begin{array}{l}\text { Knowledge4All, } \\
2017^{2}\end{array}$ \\
\hline \multicolumn{4}{|l|}{ Independent variables } \\
\hline $\begin{array}{l}\text { Daily usage of print } \\
\text { media, by country } \\
\text { (Written_Press) }\end{array}$ & $\begin{array}{l}\text { Share of respondents who read the } \\
\text { written press every day or almost } \\
\text { every day in the EU } 28 \text { countries in } \\
2017\end{array}$ & Percentage points & Statista, 2017 \\
\hline $\begin{array}{l}\text { Daily radio usage in } \\
\text { European countries } \\
\text { (Radio) }\end{array}$ & $\begin{array}{l}\text { Share of respondents who listened } \\
\text { to the radio every day or almost } \\
\text { every day in EU } 28 \text { countries in } 2017\end{array}$ & Percentage points & Statista, 2017 \\
\hline $\begin{array}{l}\text { Daily television usage } \\
\text { penetration in } \\
\text { European countries } \\
\text { (TV) }\end{array}$ & $\begin{array}{l}\text { Share of respondents who watch TV } \\
\text { on a TV set every day or almost } \\
\text { every day in the EU } 28 \text { countries in } \\
2017\end{array}$ & Percentage points & Statista, 2017 \\
\hline
\end{tabular}

\footnotetext{
${ }^{1}$ Numbeo is the world's largest database of user contributed data about cities and countries worldwide. Numbeo provides current and timely information on world living conditions including cost of living, housing indicators, health care, traffic, crime and pollution. https://www.numbeo.com/quality-of-life/indices_explained.jsp

${ }^{2}$ The Knowledge4All portal is a bilingual digital hub dedicated to all researchers, professionals, students, stakeholders, and the public. It offers easy access to the different knowledge products achieved within the Knowledge Project and to various data and publications on knowledge-related topics. http://www.knowledge4all.com/en/WorldMap
} 
INTERNATIONAL JOURNAL OF ACADEMIC RESEARCH IN BUSINESS AND SOCIAL SCIENCES Vol. 8, No. 9, Sept. 2018, E-ISSN: 2222-6990 @ 2018 HRMARS

\begin{tabular}{|c|c|c|c|}
\hline $\begin{array}{l}\text { Daily internet usage } \\
\text { penetration in } \\
\text { European countries } \\
\text { (Internet) }\end{array}$ & $\begin{array}{l}\text { Share of respondents who used the } \\
\text { internet every day or almost every } \\
\text { day in EU } 28 \text { countries in } 2017\end{array}$ & Percentage points & Statista, 2017 \\
\hline $\begin{array}{l}\text { Social network usage } \\
\text { penetration of } \\
\text { European populations } \\
\text { (Social_Networks) }\end{array}$ & $\begin{array}{l}\text { Share of individuals in European } \\
\text { countries using social networks in } \\
2017\end{array}$ & Percentage points & Statista, 2017 \\
\hline
\end{tabular}

The summary statistics for all the variables considered by this paper are presented in Table 2 . The mean values reflect the average situation on the European Union as a whole. The Indexes' average values are 164 for QLI, 0.874 for $\mathrm{HDI}$ and 58.4 for GKI, with their standard deviations from the means are the following: 17.7 for QLI, 0.0369 for $\mathrm{HDI}$ and 6.46 for GKI respectively. According to the QLI, the best reported quality of life is found in Austria (OLI=190.4) and the worst quality of life is found in Lithuania (QLI=130.3). For the Human Development Index, the highest value is registered in Germany ( $\mathrm{HDI}=0.926)$ and the lowest value is registered in Bulgaria (HDI=0.794). Nevertheless, the Global Knowledge Index is maximum in Finland ( $G K I=68.52794)$ and minimum in Bulgaria $(G K I=47)$. For the independent variables used by this paper, the average value of the share of written press readers out of the European population is of only $28 \%$, a probable decline being registered due to the evolution of new media. $64 \%$ of Finish people read written press while only $6 \%$ of Romanian people read written press materials. On EU-28 average, $50.4 \%$ of its population listens to the radio daily, with the highest share in Germany (64\%) and the lowest share in Romania (24\%). A lot of Europeans watch TV frequently because the EU-28 average is of 79.6\%, the highest share being registered in Romania (92\%) and the lowest share in Sweden (only 61\%). Despite the boom Internet has had, only $65.4 \%$ of Europeans use it, which is less than the share of TV users. In Netherlands, $91 \%$ of the population uses Internet, while only $42 \%$ of the Romanian population uses Internet. Social networks have also boomed in the last years, $57.9 \%$ of Europeans using them. The highest share of people that use social networks is in Denmark (75\%) and the lowest share is in Italy (43\%).

Table 2 Summary Statistics, using the observations $1-28$ (missing values were skipped)

\begin{tabular}{cccccc}
\hline Variable & Mean & Median & S.D. & Min & Max \\
\hline QLI & 164. & 169. & 17.7 & 130. & 190. \\
HDI & 0.874 & 0.881 & 0.0369 & 0.794 & 0.926 \\
GKI & 58.4 & 57.3 & 6.46 & 47.0 & 68.5 \\
Written_Press & 28.0 & 23.5 & 17.3 & 6.00 & 64.0 \\
Radio & 50.4 & 50.5 & 12.5 & 24.0 & 72.0 \\
TV & 79.6 & 79.0 & 7.62 & 61.0 & 92.0 \\
Internet & 65.4 & 65.0 & 12.0 & 42.0 & 91.0 \\
Social_Networks & 57.9 & 58.0 & 9.66 & 43.0 & 75.0 \\
\hline
\end{tabular}

Source: Author's Processings 
INTERNATIONAL JOURNAL OF ACADEMIC RESEARCH IN BUSINESS AND SOCIAL SCIENCES

Vol. 8, No. 9, Sept. 2018, E-ISSN: 2222-6990 @ 2018 HRMARS

\section{Applied Econometric Models}

To identify the connection between the explanatory variables and the dependent variables, this paper uses simple regression models with cross-sectional data, for the countries of the European Union.

To estimate our regression models, the paper uses the Ordinary Least Squares method (OLS), a method for estimating the regression coefficients that is generally used for one-dimensional data (time-series or cross-sectional data), with heteroskedasticity-robust standard errors.

The analysis estimates 15 simple linear regression models, each of them comprising the dependent variables (The Quality of Life index for the first set of models (1)- (5), the Human Development Index for the second set of models $\left(1^{\prime}\right)-\left(5^{\prime}\right)$ and the Global Knowledge Index for the third set of models $\left.\left(1^{\prime \prime}\right)-\left(5^{\prime \prime}\right)\right)$ and one explanatory variable. Once the coefficients for these models are computed, the paper compares the obtained Adjusted $R^{2} s$. The model with a maximum value for Adjusted $\mathrm{R}^{2}$ implies that the independent variable included in that specific regression has the highest explanatory power.

\section{Results and Interpretations}

In the first step of the modelling, each independent variable was put in the regression with the first dependent variable, the Quality of Life Index, in order to prove the determinant power of each explanatory variable for the QLI. (Table 3)

Table 3 The estimation of the Quality of Life Index (QLI) through simple regressions, OLS Method, Heteroskedasticity-robust standard errors

\begin{tabular}{|c|c|c|c|c|c|}
\hline $\begin{array}{l}\text { Dependent } \\
\text { variable } \\
\text { QLI }\end{array}$ & (1) & (2) & (3) & (4) & (5) \\
\hline Constant & $\begin{array}{c}143.616 * * * \\
(0.00)\end{array}$ & $\begin{array}{c}121.507^{* * *} \\
(0.00)\end{array}$ & $\begin{array}{c}226.529 * * * \\
(0.00)\end{array}$ & $\begin{array}{c}111.325 * * * \\
(0.00)\end{array}$ & $\begin{array}{c}- \\
136.358 * * * \\
(0.00)\end{array}$ \\
\hline Written_Press & $\begin{array}{c}0.726365^{* * *} \\
(0.00)\end{array}$ & & & & \\
\hline Radio & & $\begin{array}{c}0.866819 * * * \\
(0.00)\end{array}$ & & & \\
\hline TV & & & $\begin{array}{c}-0.76928^{*} \\
(0.07)\end{array}$ & & \\
\hline Internet & & & & $\begin{array}{c}0.81568 * * * \\
(0.00)\end{array}$ & \\
\hline Social_Networks & & & & & $\begin{array}{c}0.494475^{*} \\
(0.09)\end{array}$ \\
\hline $\mathrm{R}^{2}$ & 0.50746 & 0.404909 & 0.104821 & 0.34106 & 0.074902 \\
\hline Adjusted $\mathrm{R}^{2}$ & 0.485072 & 0.37786 & 0.064131 & 0.311109 & 0.032852 \\
\hline
\end{tabular}

Source: Author's processing in Gretl 
INTERNATIONAL JOURNAL OF ACADEMIC RESEARCH IN BUSINESS AND SOCIAL SCIENCES

Vol. 8, No. 9, Sept. 2018, E-ISSN: 2222-6990 (C) 2018 HRMARS

Notes:

(1) The brackets stand for the risk threshold.

(2) $* * *$ means $1 \%$ significant coefficients, $* * 5 \%$ significant and $* 10 \%$ significant.

The interpretations of these simple regressions are the following:

- At an increase of the share of written press with 1 unit, the Quality of Life Index will increase, on average, with 0.726365 units, ceteris paribus.

- $\quad$ At an increase of the share of daily radio listeners with 1 unit, the Quality of Life Index will increase, on average, with 0.866819 units, ceteris paribus.

- At an increase of the share of daily TV watchers with 1 unit, the Quality of Life Index will decrease, on average, with 0.76928 units, ceteris paribus.

- At an increase of the share of Internet users with 1 unit, the Quality of Life Index will increase, on average, with 0.81568 units, ceteris paribus.

- At an increase of the share of social networks' users with 1 unit, the Quality of Life Index will increase, on average, with 0.494475 units, ceteris paribus.

By comparing the Adjusted $R^{2}$ values for the previously estimated (1)-(5) models, there are medium intensity relationships between the Quality of Life Index and the share of written press readers, the share of radio listeners and the weight of Internet users of European countries. The most powerful model is the first, with and Adjusted $\mathrm{R}^{2}$ of 0.485072 , proving that the share of written press has the strongest explanatory power for the Quality of Life Index, from all the independent variables considered here. Basically, $48.5 \%$ of the variance in the Quality of Life Index is explicated by the share of written press readers of European countries.

Furthermore, the second set of estimations focuses on checking the explanatory power each of the five independent variables has on the Human Development Index of EU-28 countries, through simple linear regressions (Table 4). 
INTERNATIONAL JOURNAL OF ACADEMIC RESEARCH IN BUSINESS AND SOCIAL SCIENCES Vol. 8, No. 9, Sept. 2018, E-ISSN: 2222-6990 @ 2018 HRMARS

Table 4: The estimation of the Human Development Index (HDI) through simple regressions, OLS Method, Heteroskedasticity-robust standard errors

\begin{tabular}{|c|c|c|c|c|c|}
\hline $\begin{array}{l}\text { Dependent } \\
\text { variable } \\
\text { HDI }\end{array}$ & $\left(1^{\prime}\right)$ & $\left(2^{\prime}\right)$ & $\left(3^{\prime}\right)$ & $\left(4^{\prime}\right)$ & $\left(5^{\prime}\right)$ \\
\hline Constant & $\begin{array}{c}0.829424 * * * \\
(0.00)\end{array}$ & $\begin{array}{c}0.765762^{* * *} \\
(0.00)\end{array}$ & $\begin{array}{c}1.05763^{* * *} \\
(0.00)\end{array}$ & $\begin{array}{c}0.723171 * * * \\
(0.00)\end{array}$ & $\begin{array}{c}0.803506^{* *} \\
(0.00)\end{array}$ \\
\hline Written_Press & $\begin{array}{c}0.0015759 * * * \\
(0.00)\end{array}$ & & & & \\
\hline Radio & & $\begin{array}{c}0.00214009^{* * *} \\
(0.00)\end{array}$ & & & \\
\hline TV & & & $\begin{array}{c}-0.0023 * * * \\
(0.00)\end{array}$ & & \\
\hline Internet & & & & $\begin{array}{c}0.0023005^{* * *} \\
(0.00)\end{array}$ & \\
\hline Social_Networks & & & & & $\begin{array}{c}0.00121^{*} \\
(0.07)\end{array}$ \\
\hline$R^{2}$ & 0.544653 & 0.528440 & 0.228451 & 0.562154 & 0.100668 \\
\hline Adjusted $\mathrm{R}^{2}$ & 0.527139 & 0.510303 & 0.198776 & 0.545314 & 0.066078 \\
\hline
\end{tabular}

Source: Author's processing in Gretl

Notes:

(1) The brackets stand for the risk threshold.

(2) $* * *$ means $1 \%$ significant coefficients, $* * 5 \%$ significant and $* 10 \%$ significant.

The interpretations of these simple regressions are the following:

- At an increase of the share of written press with 1 unit, the Human Development Index will increase, on average, with 0.0015759 units, ceteris paribus.

- $\quad$ At an increase of the share of daily radio listeners with 1 unit, the Human Development Index will increase, on average, with 0.00214009 units, ceteris paribus.

- $\quad$ At an increase of the share of daily TV watchers with 1 unit, the Human Development Index will decrease, on average, with 0.0023 units, ceteris paribus.

- At an increase of the share of Internet users with 1 unit, the Human Development Index will increase, on average, with 0.0023005 units, ceteris paribus.

- At an increase of the share of social networks' users with 1 unit, the Human Development Index will increase, on average, with 0.00121 units, ceteris paribus.

By comparing the Adjusted $R^{2}$ values for the previously estimated ( $\left.1^{\prime}\right)-\left(5^{\prime}\right)$ models, there are powerful medium intensity relationships between the Human Development Index and the share of written press readers, the share of radio listeners and the weight of Internet users of European countries. The strongest model is the fourth, with and Adjusted $\mathrm{R}^{2}$ of 0.545314 , proving that the proportion of Internet users has the strongest explanatory power for the Human Development Index, from all the independent variables considered here. Basically, 54.5\% of the variance in the Human Development Index is explicated by the share of Internet users of European countries. 
INTERNATIONAL JOURNAL OF ACADEMIC RESEARCH IN BUSINESS AND SOCIAL SCIENCES Vol. 8, No. 9, Sept. 2018, E-ISSN: 2222-6990 @ 2018 HRMARS

Table 5. The estimation of the Global Knowledge Index (GKI) through simple regressions, OLS Method, Heteroskedasticity-robust standard errors

\begin{tabular}{|c|c|c|c|c|c|}
\hline $\begin{array}{l}\text { Dependent } \\
\text { variable } \\
\text { GKI }\end{array}$ & $\left(1^{\prime \prime}\right)$ & $\left(2^{\prime \prime}\right)$ & $\left(3^{\prime \prime}\right)$ & $\left(4^{\prime \prime}\right)$ & $\left(5^{\prime \prime}\right)$ \\
\hline Constant & $\begin{array}{c}49.0475^{* * *} \\
(0.00)\end{array}$ & $\begin{array}{c}39.5428^{* * *} \\
(0.00)\end{array}$ & $\begin{array}{c}97.5147^{* * *} \\
(0.00)\end{array}$ & $\begin{array}{c}27.7364^{* * *} \\
(0.00)\end{array}$ & $\begin{array}{c}38.0687^{* *} \\
(0.00)\end{array}$ \\
\hline Written_Press & $\begin{array}{c}0.334041^{* * *} \\
(0.00)\end{array}$ & & & & \\
\hline Radio & & $\begin{array}{c}0.374452^{* * *} \\
(0.00)\end{array}$ & & & \\
\hline TV & & & $\begin{array}{c}-0.4914^{* * *} \\
(0.00)\end{array}$ & & \\
\hline Internet & & & & $\begin{array}{c}0.469106 * * * \\
(0.00)\end{array}$ & \\
\hline Social_Networks & & & & & $\begin{array}{c}0.351405^{*} \\
(0.07)\end{array}$ \\
\hline $\mathrm{R}^{2}$ & 0.797141 & 0.527012 & 0.335992 & 0.761461 & 0.276185 \\
\hline Adjusted $\mathrm{R}^{2}$ & 0.789339 & 0.508820 & 0.310453 & 0.752287 & 0.248346 \\
\hline
\end{tabular}

Source: Author's processing in Gretl

Notes:

(1) The brackets stand for the risk threshold.

(2) $* * *$ means $1 \%$ significant coefficients, $* * 5 \%$ significant and $* 10 \%$ significant.

The last set of models uses the simple linear regression technique in order to estimate the relationship between the five independent variables and the Global Knowledge Index, for EU-28 countries, according to Table 5.

The interpretations of these simple regressions are the following:

- At an increase of the share of written press with 1 unit, the Global Knowledge Index will increase, on average, with 0.334041 units, ceteris paribus.

- $\quad$ At an increase of the share of daily radio listeners with 1 unit, the Global Knowledge Index will increase, on average, with 0.374452 units, ceteris paribus.

- At an increase of the share of daily TV watchers with 1 unit, the Global Knowledge Index will decrease, on average, with 0.4914 units, ceteris paribus.

- At an increase of the share of Internet users with 1 unit, the Global Knowledge Index will increase, on average, with 0.469106 units, ceteris paribus.

- At an increase of the share of social networks' users with 1 unit, the Global Knowledge Index will increase, on average, with 0.351405 units, ceteris paribus.

By comparing the Adjusted $R^{2}$ values for the previously estimated ( $\left.1^{\prime \prime}\right)-\left(5^{\prime \prime}\right)$ models, there are strong intensity relationships between the Global Knowledge Index and the share of written press readers (Adjusted $R^{2}=0.789339$, the strongest explanatory power) and the weight of Internet users of European countries (Adjusted $R^{2}=0.752287$ ). Indeed, the Global Knowledge Index is the one and 
only knowledge composite variable, being explicated to a large extent ( $78.9 \%$ and $75.2 \%$ respectively) by the share of written press readers and Internet users of European countries. Moreover, there's a medium intensity relationship between the Global Knowledge Index and the share of daily radio listeners of European countries (Adjusted $R^{2}=0.50882$ ). These findings confirm that "Radio broadcasting is one of the greatest educational tools which has ever been placed at the disposal of civilized man. It is an instantaneous, universal means of communication. It is not a new art, but is a means of multiplying the efficiency of oral communication just as the printing press multiplied the effectiveness of the written word. In addition to that, it has certain decided advantages over the printed page which it in part supplants and in part supplements" (Tyler, 1935).

It's worth reporting the medium intensity relationship between the Global Knowledge Index and the share of daily TV watchers because this Adjusted $R^{2}$ of 0.310453 is highest one from all the regressions that use the weight of TV users as an explanatory variable (models 4, 4', 4"), all these influences being indirect. Militating against television influences and referring to the title of his book, Mander (1977) says in an interview that the book is not really about four arguments, but „it's really hundreds of arguments broken down into four categories. And the categories have to do with a variety of effects that are not normally discussed. Most criticisms of television have to do with the program content. People say if there is less violence on television or less sexism on television, or less this or less that, television would be better. If there were more programs about this or more programs about that, then we'd have "good television". My own feeling is that that is true - that it's very important to improve the program content - but that television has effects, very important effects, aside from the content, and they may be more important. They organize society in a certain way. They give power to a very small number of people to speak into the brains of everyone else in the system night after night after night with images that make people turn out in a certain kind of way." (Kubiak, 2012). Therefore, the indirect relationship of television upon knowledge (and development and quality of life as well).

All in all, by comparing the Adjusted $\mathrm{R}^{2}$ for these 15 simple regression models, it can be noticed that it takes the maximum value in model (1") when the Global Knowledge Index is put in the regression with the share of written press readers. Thus, it can be stated that the variable with the highest explanatory power is the weight of written press readers.

\section{Robustness checks}

Regarding the generalizability and transferability of these results, one has to consider the previous partially validated results on the same topic, and some other empirical approaches to model validation, such as additional or split samples. The validation of these results is further strengthened by considering a random subsample of 14 observations out of the 28 European countries included in the modelling of the basic results. 
INTERNATIONAL JOURNAL OF ACADEMIC RESEARCH IN BUSINESS AND SOCIAL SCIENCES Vol. 8, No. 9, Sept. 2018, E-ISSN: 2222-6990 @ 2018 HRMARS

Table 6. The estimation of the Global Knowledge Index (GKI) through simple regressions, OLS Method, Heteroskedasticity-robust standard errors, for a random subsample

\begin{tabular}{|c|c|c|c|c|c|}
\hline $\begin{array}{l}\text { Dependent } \\
\text { variable } \\
\text { GKI }\end{array}$ & $\begin{array}{c}\left(1^{\prime \prime}\right) \\
\text { subsampled }\end{array}$ & $\begin{array}{c}\left(\mathbf{2}^{\prime \prime}\right) \\
\text { subsampled }\end{array}$ & $\begin{array}{c}\left(3^{\prime \prime}\right) \\
\text { subsampled }\end{array}$ & $\begin{array}{c}\left(4^{\prime \prime}\right) \\
\text { subsampled }\end{array}$ & $\begin{array}{c}\left(5^{\prime \prime}\right) \\
\text { subsampled }\end{array}$ \\
\hline Constant & $\begin{array}{c}50.0679 * * * \\
(0.00)\end{array}$ & $\begin{array}{c}37.5569^{* * *} \\
(0.00)\end{array}$ & $\begin{array}{c}110.384^{* * *} \\
(0.00)\end{array}$ & $\begin{array}{c}26.2965^{* * *} \\
(0.00)\end{array}$ & $\begin{array}{c}46.5024^{* *} \\
(0.00)\end{array}$ \\
\hline Written_Press & $\begin{array}{c}0.295515^{* * *} \\
(0.00)\end{array}$ & & & & \\
\hline Radio & & $\begin{array}{c}0.395368^{* * *} \\
(0.00)\end{array}$ & & & \\
\hline TV & & & $\begin{array}{c}- \\
0.657098^{* * *} \\
(0.00)\end{array}$ & & \\
\hline Internet & & & & $\begin{array}{c}0.494311^{* * *} \\
(0.00)\end{array}$ & \\
\hline Social_Networks & & & & & $\begin{array}{c}0.209462 \\
(0.11)\end{array}$ \\
\hline $\mathrm{R}^{2}$ & 0.660022 & 0.683327 & 0.486613 & 0.773049 & 0.144570 \\
\hline Adjusted $\mathrm{R}^{2}$ & 0.631691 & 0.656937 & 0.443831 & 0.754136 & 0.073284 \\
\hline
\end{tabular}

Source: Author's processing in Gretl

Notes:

(1) The brackets stand for the risk threshold.

(2) *** means $1 \%$ significant coefficients, ** $5 \%$ significant and * $10 \%$ significant.

By further estimating the Global Knowledge Index as a simple linear function of the five independent variables, the same indirect relationship with the television penetration rate and direct relationships with the written press, radio, Internet and social networks is obtained. The magnitude of the coefficients is similar to the basic results and the strength of the relationships given by the Adjusted $\mathrm{R}^{2}$ is kept, according to Table 6.

\section{Conclusions}

The paper evaluates the relationship between European consumption habits regarding written press, radio, television and internet and the life standards of the society as they are reflected in three of the most important worldwide used indexes for their measurement: the Quality of Life Index, the Human Development Index and the Global Knowledge Index.

According to the most recent data analyzed by this paper, the best reported quality of life is found in Austria; for the Human Development Index, the highest value is registered in Germany and the Global Knowledge Index is maximum in Finland. Those are all countries situated at the top of written press consumption, in the first place being Finland, where $64 \%$ of people read written press. 
At the bottom of the rankings there are Lithuania (QLI), Bulgaria (HDI) and Bulgaria (GKI), countries with low consumption of written press.

Furthermore, the findings of this study conclude that he use of radio and internet have a similar positive effect on the quality of life as written press does, although not so pronounced. It's interesting that the use of television has an opposite effect on the quality of life in EU. Thus, the country with the highest share (Romania, where $92 \%$ of the people watch TV frequently) has one of the lowest qualities of life. On the contrary, Sweden (with only $61 \%$ of its citizens watching TV) has the best quality of life in the world.

The fact that democracy can't exist without press is an axiom since the times in which The Founding Fathers conceived the American Constitution. This study demonstrates that mass media has an important role upon the quality of life, development and knowledge, expressed through three of the most worldwide used indexes for their measurement. The econometric modelling performed by this paper interestingly revealed that different types of mass media have a different impact on the quality of life. So, countries from the European Union in which written press is highly "consumed” have the highest quality of life and knowledge.

The futurist Alvin Toffler predicted in his 1990 book entitled „Powershift - Knowledge, Wealth and Violence at the edge of the 21st Century", that information will become the predominant source of power in society. The findings of this paper reveal today that information delivered in a professional way by a free press means a better life for the people of the European Union.

\section{Policy Implications}

„We need to deal with the cancer of corruption in order to achieve growth and to reduce poverty" says the former World Bank president, J.D. Wolfensohn (2005). The truth of his words is supported by vast empirical and theoretical literature. A new question arises from this diagnosis: which is the most effective way to fight corruption?

Kalenborn \& Lessmann (2013) study cross sectional and panel data on countries and come up to the following conclusion: „Democratic elections and press freedom - are complements rather than substitutes in reducing corruption. On the one hand, without a free press, the voters do not have unbiased information on corrupt activities by politicians and bureaucrats, therefore the accountability enhancing effect of democratic elections is questionable. On the other hand, just having a free press is also not a sufficient instrument in controlling corruption as people need free elections in order to punish revealed corrupt behavior".

Besides the role of informing and entertaining, press in general and written press in particular, has the essential role of a watch dog for the Government. The Founding Fathers of the American Constitution understood back in their times the importance of a free press and made sure to protect it through the first Amendment. Jefferson (1905) said "Were it left to me to decide whether we should have a government without newspapers, or newspapers without a government, I should not hesitate a moment to prefer the latter. But I should mean that every man should receive those papers and be capable of reading them."

Informed citizens will put pressure on politicians to take the best decisions in order to achieve the best quality of life in areas like purchasing power, pollution, house price, cost of living, safety index, health care, climate etc. 
This paper shows that: the share of written press has the strongest explanatory power for the Quality of Life Index, from all the considered independent variables; the proportion of Internet users has the strongest explanatory power for the Human Development Index, from all the considered independent variables; the Global Knowledge Index is the one and only knowledge composite variable, being explicated to a large extent ( $78.9 \%$ and $75.2 \%$ respectively) by the share of written press readers and Internet users of EU-28 countries. Based on these conclusions we may state that the variable with the highest explanatory power is the weight of written press readers.

One of the most important elements that can ensure a free and powerful press is its readers, which ensure its economic independence and its quality, because one of the main problems of press nowadays is its lack of founding. When a newspaper lacks in financial resources, the quality of the reporting is poorer, and we can already see a symptom of that: the investigations departments of media outlets are getting smaller and smaller. Ultimately, an important number of readers of print papers ensures the freedom of that media outlet. If a newspaper is not supporter by its readers economically speaking, then it will rely on other sources of founding which can affect its independency.

Written (print) press is the medium in which you find the most relevant information from a local, regional, national and international point of view. Why? Because the role of gate-keeper, the role of the one who decides what news the readers will receive, is still fulfilled by a senior journalist, trained for this through school and through many years of experience. We can then conclude that the people who read written press (print press) are the ones which have the best knowledge of the problems of society they live in. Having the best information allows them to choose the best leadership for their country.

In the last decade an increasing number of people get their news from social media. In this case the so-called "gate-keepers", the ones that decide what news people read, are the friends from the social network. In social media people are exposed to the news their friends share. From all the posted news of someone's friends, the algorithm of Facebook or other social networks chooses the posts that gain more engagement in likes, comments, shares and further delivers them to the person. The problem is that these kind of news are most of the time irrelevant news, tabloid news or news specially created to make us react to them and so, a person's news feed fills up with the equivalent of junk food.

This study shows that the Internet penetration rate also has an important role in explaining the Human Development Index and the Global Knowledge Index. It may be argued that many internet users are actually using Internet to read the press. For the last decade, all major printed newspapers have had online editions distributed virtually. With a minimum of media literacy, Internet can indeed be an important source of information. The difference between readers of print press and online press is that the last ones are exposed to relevant news from important and credible media outlets but also to some other kind of contents which divert their attention from the problems that really matter. The same idea is valid for radio and television, when they are used for information purposes. On the other side, television is often used for hours and hours for entertainment as a way of escaping the hardship of everyday life and such utilizations weaken the civic spirit of the society, making people less and less interested in finding how politicians are governing the country. 
INTERNATIONAL JOURNAL OF ACADEMIC RESEARCH IN BUSINESS AND SOCIAL SCIENCES Vol. 8, No. 9, Sept. 2018, E-ISSN: 2222-6990 @ 2018 HRMARS

Kalenborn \& Lessmann (2013), studying the link between corruption, democracy and press freedom, arrive at a surprising conclusion: „If there is no free press, the introduction of democratic elections in former autocratic countries might lead to even higher levels of corruption. People in democratic countries are able to vote corrupt politicians out of office. In countries with a free press, the information asymmetries between politicians and the voters decompose. Only knowing who is corrupt but not being able to vote this corrupt politician out of office does not necessarily lower the corruption level. Similarly, having the right to vote but not knowing which politician is corrupt also does not lead to lower corruption. (...) Our results imply that the level of corruption is even higher in those countries, which are democratic, but have not a sufficient high degree of press freedom." (Kalenborn \& Lessmann, 2013). Nevertheless, referring to the policy makers, Kalenborn \& Lessmann (2013) conclude: „this can be interpreted as press freedom being a superior instrument in controlling corruption compared to democracy. Thus, our policy advice is to concentrate first on a liberalization of the media, and then introduce democratic reforms in countries that suffer heavily from corruption."

Despite the fact that digital media has expanded a lot, print media still has the potential to be sustainable in mature industrialized societies and to make a critical contribution to communication and knowledge, coping with the complexity of social, political and environmental changes, as an important part of the blended media system. Still, some researchers consider that future studies are still needed in order to establish that newspapers can achieve sustainability in terms of aiding social coherence and responsibility needs (Fortunati \& O'Sullivan, 2018).

Although television, internet and social media gained a lot of influence in the last decades, the broadcasting of audio shows remains an important tool of information even in 2018 when the world is facing an extraordinary development of the podcast. Also, the increase of mobility of people who can drive for hours to get to work makes radio one of the most efficient tool for getting informed, for advertising and entertainment. The newest trend is to engage radio listeners by providing immersive experiences via the use of mobile technologies (Rosales, 2013).

Researchers have agreed that watching TV has harmful implications, especially for the young age groups and their behavioral development. Referring to his book against television, Mander (1977) argues in an interview that "one of the points of the book is that you really can't summarize complex information. And television is a medium of summary or reductionism - it reduces everything to slogans. And that's one criticism of it, that it requires everything to be packaged and reduced and announced in a slogan-type form." (Kubiak, 2012). Ansari \& Crosnoe (2016)'s findings once again prove that children's hyperactive behavior is associated to increased television watching over time, on data from the Early Childhood Longitudinal Study Birth Cohort. Moreover, television watching also influences the quality of sleep. In a study that covered preschool children, Brockmann et al (2016) concludes that the presence of a TV set in children's bedrooms is associated with significant reductions in the quality of young children's sleep, especially if the expose to television takes place in the evening and not in the first art of the day. Young preschool children's exposure to television and electronic media is associated with sleep talking, nightmares and a tiredness feeling when waking up, further harming their development. The young people are not the only age groups whose development and health are negatively affected by television watching. Some other studies validate different age groups or gender-related specificities. 
In the digital era, Internet information is highly valued. The increase in Internet penetration rates has had a strong economic and social impact. There are many studies that correlate the economic development of nations with their increased broadband access and information and communication technology, promoting Internet as a significant growth determinant (Harb, 2017 or Sepehrdoust, 2018). To a greater extent, Internet has proven positive effects on individuals and nations as a whole, but it also comes with potential risks. The findings of this paper are in line with Castellaccci \& Tveito (2018) that sum up the wide literature in the field and identify four separate channels through which Internet can shape well-being: by changing time patterns, by creating new activities, by acting as a powerful communication tool and by facilitating the access to information.

This paper's findings are in line with previous research on the use of social technologies (various platforms and networks) and their relationship to economic development (Nord et al, 2016) and social development (Din et al, 2012; Campisi et al, 2015) or the both (Growiec et al, 2018) but it's the first study that deals with the impact of various mass media indicators upon three different indexes at one time, thus offering a complex and multidimensional perspective.

\section{Corresponding Author}

Florescu Decebal-Remus, "Babeș-Bolyai" University Cluj-Napoca, Faculty of Political, Administrative and Communication Sciences, Romania, Email: remus_florescu@yahoo.com, 71 General Moșoiu Street, Cluj-Napoca, 400132.

\section{References}

Ansari, A. \& Crosnoe, R. (2016) Children's hyperactivity, television viewing, and the potential for child effects, Children and Youth Services Review 61: 135-140.

Barthel, M. (2016) Newspapers: Fact Sheet in State of the News Media 2016, Pew Research Center's Journalism Project, citing Nielsen Scarborough's 2015 Newspaper Penetration Report, available at https://assets.pewresearch.org/wpcontent/uploads/sites/13/2016/06/30143308/state-of-the-news-media-report-2016final.pdf

Bird, S.E. (1992) For Enquiring Minds: A Cultural Study of Supermarket Tabloids. Knoxville: University of Tennessee Press, 248 pages.

Britannica Online Encyclopedia, Britannica.com.

Brockmann, P., Diaz, B., Damiani, F., Villarroel, L., Nunez, F. \& Bruni, O. (2016) Impact of television on the quality of sleep in preschool children, Sleep Medicine 20: 140-144.

Campisi, J., Folan, D., Diehl, G., Kable, T. \& Rademeyer, C. (2015) Social media users have different experiences, motivations and quality of life, Psychiatry Research, 228: 774-780.

Castellacci F. \& Tveito V. (2018) Internet use and well-being: a survey and a theoretical framework, Research Policy, 47: 308-325.

Coyne, C. J. \& Leeson P.T. (2004) Read all about it! Understanding the role of media in economic development. KYKLOS, Vol. 57: 21-44, available at: http://www.peterleeson.com/Kyklos-Media.pdf.

Diggs-Brown B. (2012) Strategic Public Relations: Audience Focused Practice. Wadsworth Publishing Co Inc (12 Aug. 2011). ISBN-10: 053463706X 
INTERNATIONAL JOURNAL OF ACADEMIC RESEARCH IN BUSINESS AND SOCIAL SCIENCES

Vol. 8, No. 9, Sept. 2018, E-ISSN: 2222-6990 @ 2018 HRMARS

Din N., Yahya S. \& Kassim R.S.R. (2012) Online Social Networking for Quality of Life, Procedia-Social and Behavioural Sciences 35: 713-718.

Fortunati L. \& O'Sullivan J. (2018) Situating the social sustainability of print media in a world of digital alternatives, Telematics and Informatics, Article in press, https://doi.org/10/1016/j.tele.2018.04.005 .

G4 Sector Disclosures (2014) Global Reporting Initiative, Media, based on the 'GRI Media Sector Supplement, Stichting Global Reporting Initiative (GRI), Amsterdam, Available at https://www.globalreporting.org/resourcelibrary/GRI-G4-Media-Sector-Disclosures.pdf .

Growiec K., Growiec J. \& Kaminski B. (2018) Social network structure and the trade-off between social utility and economic performance, Social Networks, 55: 31-46.

Harb G. (2017) The economic impact of the Internet penetration rate snd telecom investments in Arab and Middle Eastern countries, Economic Analysis and Policy 56: 148-162.

Jefferson T. (1905) The Works of Thomas Jefferson, vol. 5 (Correspondence 1786-1789), Paul Leicester Ford, Part of: The Works of Thomas Jefferson, 12 vols.

Kalenborn C. \& Lessmann C. (2013) The impact of democracy and press freedom on corruption: Conditionality matters, Journal of Policy Modeling, 35: 857-886.

Kubiak W.D. (2012) "Nancho Consults Jerry Mander". Archived from the original on 2012-09-08. Retrieved 2010-11-09, available at https://archive.is/20120908003052/http://www.nancho.net/advisors/mander.html

Lindgren, A. (2004). "Radio" Encyclopedia of Children and Childhood in History and Society, (2), 707709. Retrieved from http://www.faqs.org/childhood/Pa-Re/Radio.html

Liu B. \& McConnell J. (2013), The role of the media in corporate governance: Do the media influence managers' capital allocation decisions?, Journal of Financial Econometrics, 110: 1-17.

Locksley G. (2009) The media and development: what's the story? , World Bank working paper; no. 158, ISBN 978-0-8213-7834-2 (electronic), The World Bank, Washington D.C..

Mander J.I. (1977) Four arguments for the elimination of television, New York, HarperCollins, 375 pages, ISBN 978-0-688-08274-1.

Media Development's Role in Social, Economic and Political Progress (2014) Media Development Investment Fund (MDIF), New York, available at https://www.mdif.org/media-developmentsrole-in-social-economic-and-political-progress-literature-review/.

Nord J.H., Lee T.R., Cetin F., Atay O. \& Paliszkiewicz J. (2016) Examining the impact of social technologies on empowerment and economic development, International Journal of Information Management, 36: 1101-1110.

Novel A.S., Guseva M., Nakaa M., Nove AS., Pekkala K., Souberou B. \& Stouli S. (2008) Press freedom and development - An analysis of correlations between freedom of the press and the different dimensions of development, poverty, governance and peace, United Nations Educational Scientific and Cultural Organization, Communication and Information Sector, Division for Freedom of Expression, Democracy and Peace, Paris.

Quality of life indicators (2015) Eurostat online publication, ISSN 2443-8219, http://ec.europa.eu/eurostat/statistics-

explained/index.php?title=Quality_of_life_indicators. 
Postman, N. (2006). Amusing Ourselves to Death: Public Discourse in the Age of Show Business. New York, N.Y: Penguin Books.

Rees F. (2005) Johannes Gutenberg: Inventor of the Printing Press. Compass Point Books.

Rosales R.G. (2013) Citizen participation and the uses of mobile technology in radio broadcasting, Telematics and Informatics, 30: 252-257.

Sepehrdoust H. (2018) Impact of information and communication technology and financial development on economic growth of OPEC developing economies, Kasetsart Journal of Social Sciences, XXX: 1-6.

Sterling C. H. (2004) Encyclopedia of Radio 3-Volume, Routledge.

Toffler A. (1990) Powershift: Knowledge, Wealth and Violence at the Edge of the 21st Century, Bantam Books, 585 pages

Trivedi R., Patel J. \& Acharya N. (2018) Causality analysis of media influence on environmental attitude, intention and behaviors leading to green purchasing, Journal of Cleaner Production, 196: 11-22.

Tyler, T.F. (1935). Radio and Education. The Phi Delta Kappan, 17(4), 115-117. Retreived from http://www.jstor.org/stable/20258384.

Walker C.B. (2016) The direction of media influence: Real-estate news and the stock market, Journal of Behavioral and Experimental Finance 10: 20-31.

Weber J. (2005) Straßburg 1605: Die Geburt der Zeitung, in Jahrbuch für Kommunikationsgeschichte, 7: 3-27.

Wolfensohn J. D. (2005) Voice for the World's poor: Selected Speeches and Writings of World Bank President James D. Wolfensohn 1995-2005, Washington, DC: Worldbank. 